\title{
Approval and Disapproval Expressions in English and Arabic: A Contrastive Study
}

\author{
Abeer Hadi Salih \\ Prof. Asst. Department of English- College of Education for Women
}

AL Iraqia University

\begin{abstract}
Any language in the world wide has different expressions and terms that convey approval or disapproval that language speakers may use in their daily life. English language for instance, is full of such expressions and can be found in any situation needs to. The present research studies approval and disapproval in English with their counterparts in Arabic as a contrastive study. It tries to search for those terms or sentences that are used to express approval and disapproval in English with their counterparts in Arabic. It aims to highlight the points of similarities and differences between those expressions that are used to state approval and disapproval in the two languages. Also the study includes a contrastive analysis to the expressions of approval and disapproval in English with their equivalents in Arabic in order to come up with the conclusions. It concluded that the approval and disapproval expressions in English language are similar to their counterparts in Arabic language but differ in two points. Firstly in Arabic language main verbs are used to convey approval and disapproval whereas in English are not. Secondly, in English language the exclamatory style is used to express approval in contrast, Arabic language is not. Researchers, teachers, translators and any who cares about English language and linguistics can get benefit from this study, precisely because it includes a comparison between two languages, English language and Arabic, with several types of expressions and terms that are being actually used to express approval and disapproval.
\end{abstract}

Keywords: approval and disapproval expressions in English and Arabic

\section{Introduction}

\section{Problem Statement}

Within everyday speeches and writings diverse types of words or expressions can be noticed that refer to what is meant by approval or disapproval of the speaker or the hearer. These words or expressions may come in the forms of verbs, nouns, adjectives, adverbs, exclamations, prepositions, or even phrases and sentences. They eventually carry either the approval or disapproval of either the sender or the recipient of the message. Approval means a message expressing a favourable opinion and, a feeling of liking something or someone good, whereas, disapproval means a feeling of disliking something or what someone is doing, and the belief that someone or something is bad or wrong. On the other hand, approval in Arabic language means acceptance and permission for doing a specific action and showing full agreement with the speaker. Whereas disapproval, refers to the refusal and not acceptance of doing an action and showing disagreement with the speaker. These expressions may cause problems or confusion in much of the situations in which they are mentioned to either the addresser or the addressee. Sometimes, the way of stating approval or disapproval cause ambiguity of what is meant precisely to the hearer. In addition, ambiguity rises from multiple meaning words that are being used to express approval and disapproval within the addresses or speeches.

1.2 Hypotheses: This study is based on the following hypotheses:

There is a great similarity between the approval and disapproval expressions in English .

Points of differences between the approval and disapproval expressions in English with their equivalent in Arabic are few. 
1.3 Aims of the Study: The present study aims at Investigating the approval and disapproval expressions in English determining a possible correspondence between them and their Arabic equivalents .

Shedding light on the points of similarities and differences of approval and disapproval expressions in the two languages English and Arabic

1.4 The Procedures of the Study: The procedures to be adopted in this study are as follows:

Giving a general concept about approval and disapproval expressions in English and their counterparts in Arabic .

Investigating the approval and disapproval in English with their equivalent in Arabic.

Carrying out a contrastive analysis between approval and disapproval expressions in the two languages and get the results.

Highlighting points of differences and similarities of approval and disapproval expressions in the two languages.

Drawing conclusions from the findings of the study.

1.5 Limits of the Study: The study is limited to:

1.Standard English and standard Arabic. 2.Syntactic, and pragmatic analysis to the approval and disapproval expressions in both languages English and Arabic .

\subsection{Value of the Study:}

The present study is valuable to students, researchers and teachers of both English and Arabic. It is also valuable as a contrastive study because it sheds light on the similarities and differences between the two languages and this contributes to researchers investigating the existence of language universals.

\subsection{Approval and Disapproval:}

The speech act of disapproval occurs when a speaker directly or indirectly says no to a request or invitation. Refusal or disapproval is a face-threatening act to the listener/requestor/inviter, because it contradicts his or her expectations, and is often realized through indirect strategies. Thus, it requires a high level of pragmatic competence (Chen, 1996). Three major types of indirect refusals are identified, including: excuses/reason, request for information or clarification, and suggesting alternatives. (Beebe et al, 1990) Direct disapprovals refer to phrases such as "No, won't" or "I refuse". Indirect disapprovals are indirect strategies speakers use to minimize the offense to the hearer and they can include, for example, statements of excuses, regrets, some other alternatives, or postponement. (ibid) On the other hand, approval, in which the refuser expresses his/her consent before actually making the refusal itself (e.g. "Yes, but ..."); and (solidarity or empathy, in which the refuser demands the solidarity of the requester by asking for his/her sympathy (e.g. I realise you are in a difficult situation, but ..."). By uttering, "I accept" or using equivalent words, an offeree becomes committed to the terms of the offer. Approval as a show of support from one speaker for a belief or proposition expressed by another. Disapproval suggests that there are frequent, normative patterns associated with each action (Sacks, 1987). Whereas approvals are usually produced quickly and unambiguously, disapproval is frequently delayed, and often prefaced with an element of agreement, such as in the case of the ubiquitous 'yes, but'. Moreover, adjuncts refer to those expressions that accompany disapprovals but do not constitute disapprovals by themselves. They include five subtypes: i) positive opinion, in which the refuser expresses that the request is a good idea but he/she cannot comply it (e.g. This is a great idea, but ...); ii) willingness, in which the refuser expresses that he/she would be willing to perform the request but he/she cannot e.g. l'd love to help, but ...); iii) gratitude, in which the refuser softens his/her refusal by thanking his/her interlocutor (e.g. "Thanks a lot, but). (ibid)

\subsection{Asking for Approval}

Sometimes we are not sure if it's a good idea to do something. So we need useful expressions for asking if other people agree with an idea or intended action. Here are ten phrases. (Boander, 2013:23-25)

\section{Ten Expressions to Use in Speaking and Writing}

\section{Do you think it's all right to do it?}


What do you think about (me doing that?)

Do you think / reckon I ought to (do it?)

What would you say if I (did it?)

Would you approve of (doing something?)

What is your attitude to the idea of...

Are you in favour of (me doing something?)

You are in favour of ... aren't you?)

Do you think anyone would mind if $I . .$.

Do you think it would be really awful if $I . .$.

\subsection{Expressing Approval:}

These are some of the expressions that are used to express approval in spoken and written English:

\section{Good! Excellent! Right}

That's fine.

That's nice.

Well done

\section{Perfect}

It looks / sounds pretty good

I approve of (them / you)

What a success

Go ahead.

Let's do it.

I'm all for it

You couldn't have done better.

I hope so.

I would like that. (ibid: $30-35$ )

\subsection{Disapproving of an action}

Sometimes we hear about an action that somebody else has done and we feel very negative about it. Here are ten phrases that English people use to show their disapproval. (Leech, 2014: 50-55)

Ten Expressions to use in Speaking and Writing

1. I don't think much of that.

2. How appalling / dreadful!

3. I'm utterly appalled / disgusted.

4. I'm dead against people doing...

5. It shouldn't be allowed! 


\section{What a rotten / mean thing to do}

\section{I take a very dim view of people doing.}

\section{Who do they think they are?}

\section{How can people do things like that?}

10. Whatever next? (Malcolm, 1990: 44-49)

When expressing disapproval, you should try to avoid strong terms. For this reason a negative expression is often preferable.

It/ That isn't/ wasn't a very good idea.

It/ That isn't/ wasn't a very nice thing to say/ do

It/ That isn't/ wasn't so interesting as we had expected.

Disapproval may also be expressed by using too.

To make such statements less abrupt and final, we may begin them with Well, personally I think..., or Don't you think...? (ibid)

\subsection{Approval and Disapproval in Arabic:}

Arabic language awards the speakers with diverse means to express one's position and the language is more accurate in selecting the most appropriate methods to express his opinion or his position. Between acceptance and rejection a great distance, and both have different degrees, each mode of Arabic language reveals the degree of acceptance or rejection at the speaker.There are several styles in Arabic to express approval and disapproval, depending on the terms the speakers use the way they use them. Styles of approval involve the style of command, style of wishing and hope, style of praising, style of awakening of a desire, whereas styles of disapproval involve prohibition, dispraising and interrogation. (الاوسي), 1980, 60-55 )

\subsection{Approval Styles in Arabic:}

\subsubsection{Command Style:}

Expressing approval in Arabic the speaker may use the command style to get the approval of the listener using the form

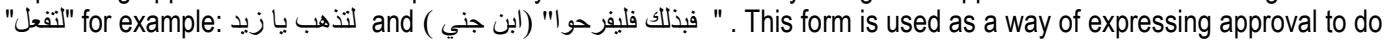
something from the addressee but in a polite way. (الزبيدي 1965: 43-43)

\subsubsection{Praising style:}

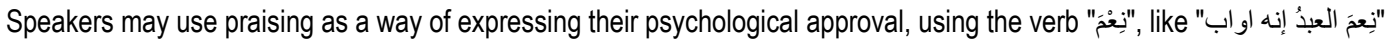

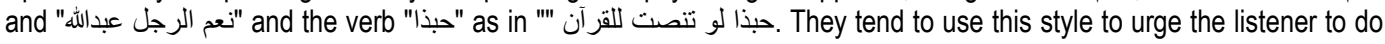
things willingly.(هادي نهر 1978)

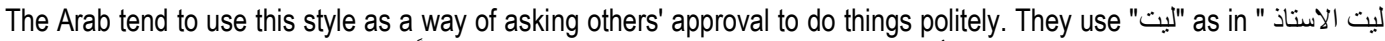

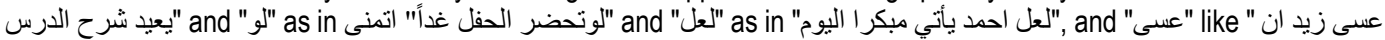
(طاهر سلمان،1983: 66-69) ."ينطلق

\subsection{Disapproval Styles in Arabic}

Arab speakers have several styles to express disapproval. They may use prohibition and dispraise or even interrogative terms to state their refusal. The following are the common styles that are used to express disapproval.

\subsubsection{Prohibition Style}

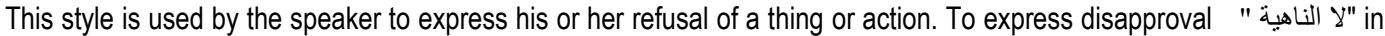

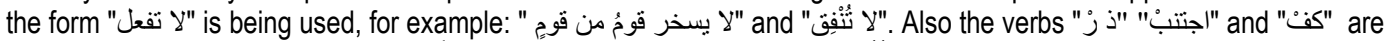

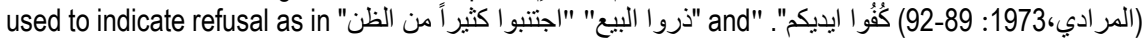




\subsubsection{Dispraising Style:}

Arab sometimes tend to use dispraise terms and verbs to express their psychological disapproval of things and deeds.

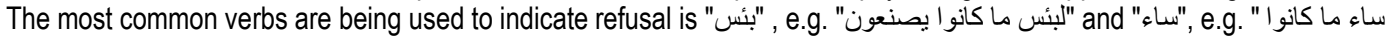
(الميالي، 2006: 802 ) . يعطون

\subsubsection{Interrogative Style:}

This style is the most absolutely important way in communication. It is an inclusive way of expressing not only disapproval but also other meanings, like persuasion, denial and exclamation. Interrogatory expressions and clauses are used to

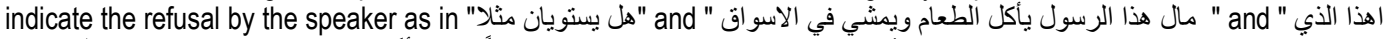

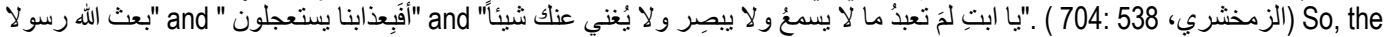
context in which the interrogative clauses and expressions occur helps the speaker in indicating what does he or she means specifically.

\section{Contrastive Analysis:}

After a comprehensive study to approval and disapproval in English with their counterparts in Arabic, a contrastive analysis to both terms and expressions can be carried out. Firstly the approval in English is expressed using praising, interrogative and exclamatory styles. Within praising the speaker uses expressions like excellent, great, that's fine and so on. In Arabic the same style is being used to express approval as in "نعِنَ الاقتر اح " , " جيد، رائع and so on. The other style is command by which the speaker ask the approval of the listener using expressions may be understood as commands, as in let's leave and go ahead.

In Arabic the same happens like " لترحل يازيد using the form "لتفعل " to get the approval of the addressee. Then comes whishing style to express approval by using hope and would and wish in expressions e.g. I would, I hope so, I wish to

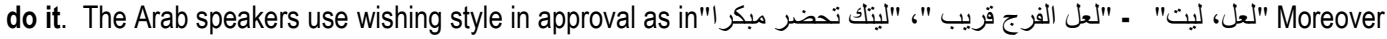
in English speakers tend to use interrogatory style to show approval like would you approve of? / Do you think? Besides, English speakers use the exclamatory style to show approval as in what a success! On the other hand, there is the disapproval. To express refusal in English there is dispraise style as in how dreadful / that isn't good / I am disgusted.

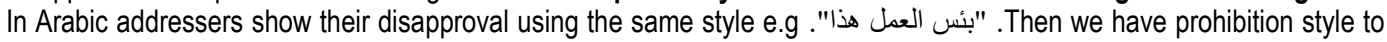

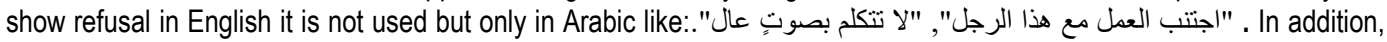
there is the interrogatory style which is used in both languages to state the disapproval. English addressers use it as in: who do you think they are?, what a mean thing to do?, don't you think that ...? Arabic users show refusal by interrogative expressions in this wa." هل يسنويان ؟" "أهذا الذي تريده , له

Accordingly, the approval and disapproval expressions in the two languages contain the first person addressing the second one in the active voice. In addition, these expressions are in the present tense with different structures. Also, the expressions included the indicative, (including the interrogatives), imperative, and subjunctive mood. Furthermore, English and Arabic approval and disapproval expressions are phrases, clauses and rarely a full sentence. Sometimes, the addresser uses a single word to express approval or disapproval, e.g. "ok","yes", "no" , " Adjectives are used in expressing approval, like: "right", "great" "باءئع، جميل" and disapproval like: "dreadful, disgusted". In Arabic, main verbs are used in this case like:"باء", "بئس".

\section{Conclusion:}

This section is specified for the conclusions that the current study has come up with. At the end of the detailed survey of the approval and disapproval expressions in English with their counterparts in Arabic, several points have emerged and they are as follows:

\section{Points of Similarities:}

Expressions of approval in English are similar to their equivalents in Arabic in time and tense and structure.

Disapproval expressions in English are similar to their equivalents in Arabic in time and tense and structure.

Approval and disapproval in the two languages contain all types of mood. 
The two languages use praising, wishing and command as a style of expressing approval.

Both of English language and Arabic language use dispraising, prohibition, and interrogation as a style of expressing disapproval.

Single words are being used to express approval and disapproval in English language and Arabic one.

All of approval and disapproval expressions in the two languages are in the active voice with a first person addresser.

\section{Points of Differences:}

The exclamatory style is being used in English language to express approval, whereas in Arabic this is not so. Arabic language differs from English language in using main verbs to express both approval and disapproval.

\section{Bibliography}

[1] Alexandropoulou, M. (2014). Detection of Agreement and Disagreement:

$$
\begin{aligned}
& \text { i. An investigation of linguistic coordination and } \\
& \text { ii. conversational features. Unpublished thesis. University of } \\
& \text { iii. Washington. U.S.A }
\end{aligned}
$$

[2] Austin, J. L. (1962). How To Do Things With Words, Oxford: Clarendon

[3] Press.

[4] Beebe, L. M., Takahashi, T. \& Uliss-Weltz, R. (1990). Pragmatic transfer in

[5] ESL refusals. In: R. Scarcella, E. Andersen, \& S. Krashen (Eds.).

[6] --------Developing communicative competence in a second language. New

[7] York: Newbury House.

[8] Bolander, B.(2013) Language and Power in Blogs: Interaction,

[9] disagreements and agreements (Pragmatics \& Beyond New Series).

[10] Cambridge: Cambridge University Press.

[11] Chen, H.J. (1996). Cross-cultural comparison of English and Chinese

[12] metapragmatics in refusal. Indiana University.

[13] Goodale, Malcolm. (1990). Language of Meetings.

[14] Johnson, F. (2006). Agreement and Disagreement: A Cross-Cultural

[15] Comparison. Unpublished thesis. Birkbeck, London University.

[16] Leech, G. (2014). The Pragmatics of Politeness. Oxford: Oxford University

[17] Press, Studies in Sociolinguistics.

[18] Liew, T.S., (2016). Comparison of Agreement and Disagreement

[19] Expressions between Malaysian and New Headway Course Books.

[20] Unpublished thesis. Raffles University Iskandar. Malaysia.

[21] Pearson, E. (1990). Agreement and Disagreement in Conversational 
[22] Discourse and ESL/EFL Materials. Unpublished thesis. Japan:

[23] Sophia University.

[24] Sacks, H. (1987). On the Preferences for Agreement and Continuity in

[25] Sequences in Conversation. In G. Button \& J. Lee (Eds.), Talk and

[26] Social Organization. Cleve don: Multilingual Matters.

[27] Searle J R (2002). Consciousness and Language. Cambridge: Cambridge

[28] University Press .

[29] Searle, John R. (1969) Speech Acts: An Essay in the Philosophy of

a. Language, Cambridge and New York: Cambridge University

b. Press.

[30] Y. George. (1996). Pragmatics. Oxford: Oxford University Press 